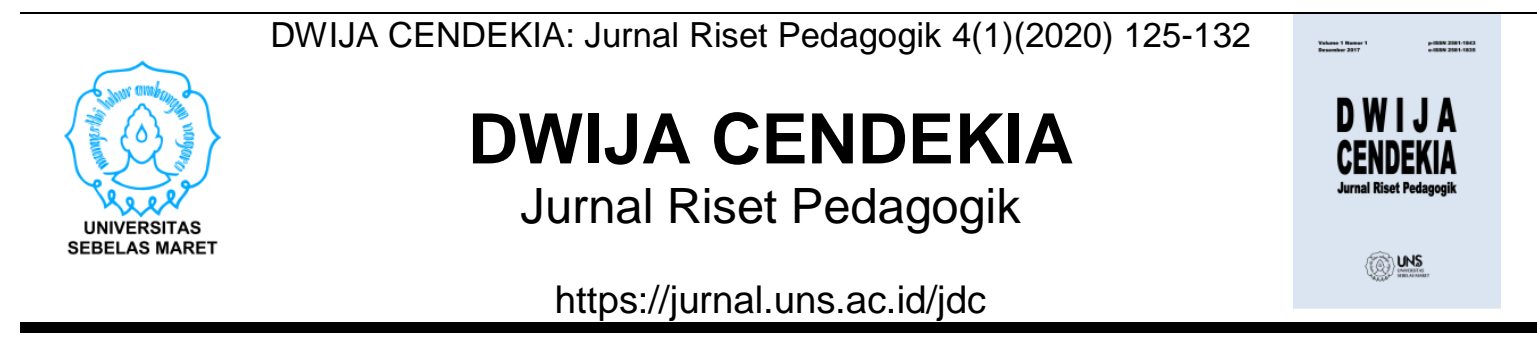

\title{
Minat Siswa Kelas V Pada Ekstrakurikuler Renang di SD Negeri 216 Palembang
}

\author{
Yeni Indah Kartika Sari, Farizal Imansyah \\ Universitas PGRI Palembang \\ yeniiks76@gmail.com
}

\section{Sejarah Artikel}

diterima 12/04/2020

disetujui 23/08/2020

diterbitkan 31/08/2020

\begin{abstract}
The purpose of this study was to determine how much interest the fifth grade students had in swimming extracurriculars at 216 Negeri SD Palembang. This research method is survey. Data collection techniques using a questionnaire. The sample of the research was grade $V$ students who took part in the swimming extracurricular totaling 26 people. This data analysis technique with quantitative descriptive method with the percentage of techniques with direct problem analysis and can see the situation in progress. The results showed a high percentage of internal interest factors of $79.80 \%$, external interests of $80.40 \%$. Judging from the percentage, each of the factors of interest has a fairly high contribution in influencing the interest in participating in the extracurricular swimming of fifth grade students at 216 Negeri SD Palembang.

Keywords: SInterests and Extracurricular swimming
\end{abstract}

\section{Abstrak}

Tujuan penelitian ini adalah untuk mengetahui seberapa besar minat siswa kelas $\mathrm{V}$ pada ekstrakurikuler renang di SD Negeri 216 Kota Palembang. Metode penelitian ini yaitu survei. Teknik pengambilan data menggunakan angket. Sampel penelitian yaitu siswa kelas $V$ yang mengikuti ekstrakurikuler renang yang berjumlah 26 orang. Teknik analisis data ini dengan metode deskriptif kuantitatif dengan persentase teknik dengan analisis masalah secara langsung dan dapat melihat keadaan sedang berlangsung. Hasil penelitian menunjukan persentase yang tinggi yaitu faktor minat internal sebesar $79,80 \%$, minat eksternal $80,40 \%$. Dilihat dari persentasenya setiap faktor-faktor minat memiliki sumbangan yang cukup tinggi dalam mempengaruhi minat mengikuti ekstrakurikuler renang siswa kelas $V$ di SD Negeri 216 Palembang.

Kata kunci: Minat, Ekstrakurikuler Renang, Sekolah Dasar

e-ISSN 2581-1835

p-ISSN 2581-1843

This work is licensed under a Creative Commons Attribution-ShareAlike 4.0 International License. 


\section{PENDAHULUAN}

Salah satu olahraga paling populer adalah renang, ternyata perkembangan olahraga renang memiliki sejarah yang panjang. Pada tahun 1538, Nicolas Wynman, profesor bahasa anak Jerman, menulis buku pertama tentang renang. Perlombaan renang di Eropa bermula pada sekitar tahun 1800 , dan sebagian besar peserta menggunakan gaya dada. Gaya rangkak depan, ketika itu dipanggil gaya trudgen, diperkenalkan pada tahun 1873 oleh John Arthur Trudgen yang menirunya dari suku Indian. Renang merupakan salah satu cabang olahraga dalam Olimpiade Athena 1896. Pada tahun 1900 , gaya punggung dimasukkan ke dalam Perlombaan Olimpiade sebagai suatu acara. Pada tahun 1902, gaya trudgen terbaik dimenangi oleh Richard Cavill, menggunakan tendang keribas. Persatuan renang dunia yang pertama, Federation Internationale de Natation, dibentuk pada tahun 1908. Gaya kupu-kupu yang pada awalnya merupakan salah satu kelainan gaya dada diterima sebagai suatu gaya tersendiri pada tahun 1952(Manulang, 2016:1).

Imansyah (2017:3) mengungkapkan bahwa aktivitas air (renang) adalah kegiatan atau olahraga yang dilakukan didalam air dan tempat olahraga tersebut berbeda dengan kehidupan sehari-hari manusia. Perenang mendapatkan hambatan yang disebabkan oleh dorongan balik arus air. Oleh karena itu untuk dapat berenang dengan cepat, perenang harus dapat menguasai prinsip mekanis dalam renang secara umum. Prinsip renang tersebut adalah prinsip hambatan, dorongan, dan daya apung. renang merupakan jenis olahraga yang dilakukan dalam air atau seluruh aktivitas yang berkaitan dengan air sebagai medianya yang mana di dalamnya mencakup permainan, perlombaan, bahkan hal-hal yang berhubungan dengan keselamatan. Dalam renang terdapat istilah hambatan dan dorongan mengingat seseorang saat berenang akan melawan arus air, sehingga dibutuhkan dorongan agar dapat melawan hambatan tersebut.

Arifin (2013:5) menjelaskan gaya dalam renang yang pada umumnya digunakan diantaranya adalah: 1) Gaya Bebas, 2) Gaya Kupu-kupu, 3) Gaya Punggung, 4) Gaya Dada. Keempat gaya ini merupakan gaya dari renang yang dipertandingkan dalam kejuaraan renang. Apabila telah mengenal tentang gaya dalam renang, maka selanjutnya adalah mulai dengan bagaimana mengenal air dan apa yang dilakukan apabila ingin belajar renang.

Muhaimin dalam Khaliq (2017:412). Mengungkapkan bahwa minat adalah kecenderungan subjek yang menetap untuk merasa tertarik pada bidang studi atau pokok bahasan tertentu dan senangmempelajari materi tersebut. Minat merupakan kecenderunganafektif seseorang untuk membuat pilihan aktivitas, kondisi-kondisi individual dapat merubah minat seseorang sehingga dapat dikatakan minat itu tidak stabil. Minat adalah perhatian, kesukaan, kecenderungan hati kepada sesuatu. Minat adalah kecendrungan hati yang tinggi terhadap sesuatu keinginan. Berdasarkan pengertian diatas dapat 
dipahami bahwa minat adalah kecenderungan seseorang terhadap sesuatu yang mereka sukai.

Pralita (2015:13) menjelaskan bahwa faktor yang mempengaruhi minat ada 2 (dua) yaitu faktor intrinsik dan faktor ekstrinsik. Faktor intrinsik adalah faktor yang berasal dari dalam diri individu seperti kemauan, kebutuhan dan motivasi atau dorongan sedangkan faktor ekstrinsik adalah faktor yang berasal dari luar dirinya atau karena pengaruh dari orang lain atau lingkungannya seperti dukungan keluarga, lingkungan sekolah dan mass media.

1. Faktor intrinsik yaitu sesuatu yang timbul dari dalam individu sendiri tanpa ada pengaruh dari luar. Faktor intrinsik tersebut meliputi: kemauan, kebutuhan dan motivasi. Kemauan adalah dorongan yang terarah pada tujuan yang dikehendaki oleh akal pikiran. Dorongan ini akan melahirkan timbulnya suatu perhatian terhadap suatu objek, sehingga dengan demikian akan memunculkan minat individu yang bersangkutan.

2. Faktor ekstrinsik adalah faktor yang dipengaruhi dari luar individu (Bimo Walgito, 1997:89). Faktor ekstrinsik tersebut diantaranya meliputi dukungan keluarga, lingkungan sekolah dan mass media. Dukungan adalah suatu sikap, pemberian bantuan atau perhatian. Dalam hal ini, dukungan yang paling besar berasal dari orang tua diartikan sebagai sikap atau pemberian bantuan, perhatian dan rasa sayang yang diberikan orang tua kepada anaknya atau anggota keluarga. Pemberian dukungan dapat berupa teguran, pengarahan, membantu dalam menghadapi kesulitan ataupun menegur, memberi hukuman apabila berbuat kesalahan.

Pralita (2015:6) ekstrakurikuler mempunyai arti berada diluar program yang tertulis didalam kurikulum seperti latihan kepemimpinan dan pembinaan siswa. Ekstrakurikuler adalah kegiatan untuk membantu memperlancar perkembangan individu siswa sebagai manusia seutuhnya. Menurut catatan Tata Usaha jumlah siswa yang mengikuti ekstrakurikuler renang selalu diatas 20 orang. Banyaknya siswa dalam mengikuti ekstrakurikuler renang di SDN 216 Palembang membuat peneliti berpikir, dorongan apa yang kemudian mereka harapkan untuk ikut bergabung dalam ekstrakurikuler renang tersebut. Bagaimana minat dibalik keikut-sertaan mereka pada ekstrakurikuler renang tersebut. Menganalisis minat yang muncul pada siswa mengikuti ekstrakurikuler renang maka diperlukan penelitian yang mendalam. Maka dari itu peneliti berkeinginan melakukan studi terhadap siswa ekstrakurikuler renang pada Sekolah dasar tersebut. Adapun judul penelitian adalah "Minat Siswa Kelas V Pada Ekstrakurikuler Renang Pada Sekolah Dasar Negeri 216 di Palembang".

\section{METODE}

Adapun objek dalam penelitian ini adalah siswa yang mengikuti ekstrakurikuler renang SD Negeri 216
Palembang. Teknik pengambilan sampel pada penelitian ini adalah menggunakan total 
sampling. Arikunto (2006: 134) menjelaskan total sampling adalah jenis penggunaan sampel dengan mengambil seluruh populasi untuk dijadikan subjek penelitian. Mengingat siswa yang mengikuti ekstrakurikuler renang berjumlah 26 orang, maka 26 orang akan dijadikan sampel penelitian. Berdasarkan pendapat di atas, objek/subjek dalam penelitian ini berjumlah 26 orang yang mengikuti kegiatan ekstrakurikuler cabang olahraga Renang.

Tabel 1. Sampel Penelitian

\begin{tabular}{|c|c|c|}
\hline NO & Jenis Kelamin & Jumlah \\
\hline 1 & Putra & 12 \\
\hline 2 & Putri & 14 \\
\hline \multicolumn{2}{|c|}{ Jumlah } & 26 \\
\hline
\end{tabular}

\section{Sumber : Tata Usaha Sekolah dasar Negeri No 216 Kota Palembang}

Metode yang digunakan yaitu deskripsi kuantitatif dengan teknik survey. Pada analisis ini semua pertanyaan dari responden disusun menurut kelompoknya dan diolah dalam bentuk persentase. Adapun indikator-indikatornya meliputi.

\section{a) Faktor Internal}

Dari variabel minat didapat dari seluruh jawaban faktor internal. Hasil analisis seberan angket untuk mengetahui besarnya minat siswa yang mengikuti ekstrakurikuler renang SD Negeri 216 Palembang ditinjau dari aspek internal berdasarkan data yang diperoleh. setelah di analisis menggunakan rumus di atas, dapat dilihat pada tabel 2 di bawah ini:

Tabel 2 Persentase Faktor Internal

\begin{tabular}{|c|c|c|}
\hline Keriteria & Persentase & Frekuensi \\
\hline Ya & 86,97 & 23 \\
\hline Tidak & 13,03 & 3 \\
\hline
\end{tabular}

Sumber : Peneliti (2019)

Dari pembahasan di atas, akan di reduksi dalam bentuk diagram batang di bawah ini : 


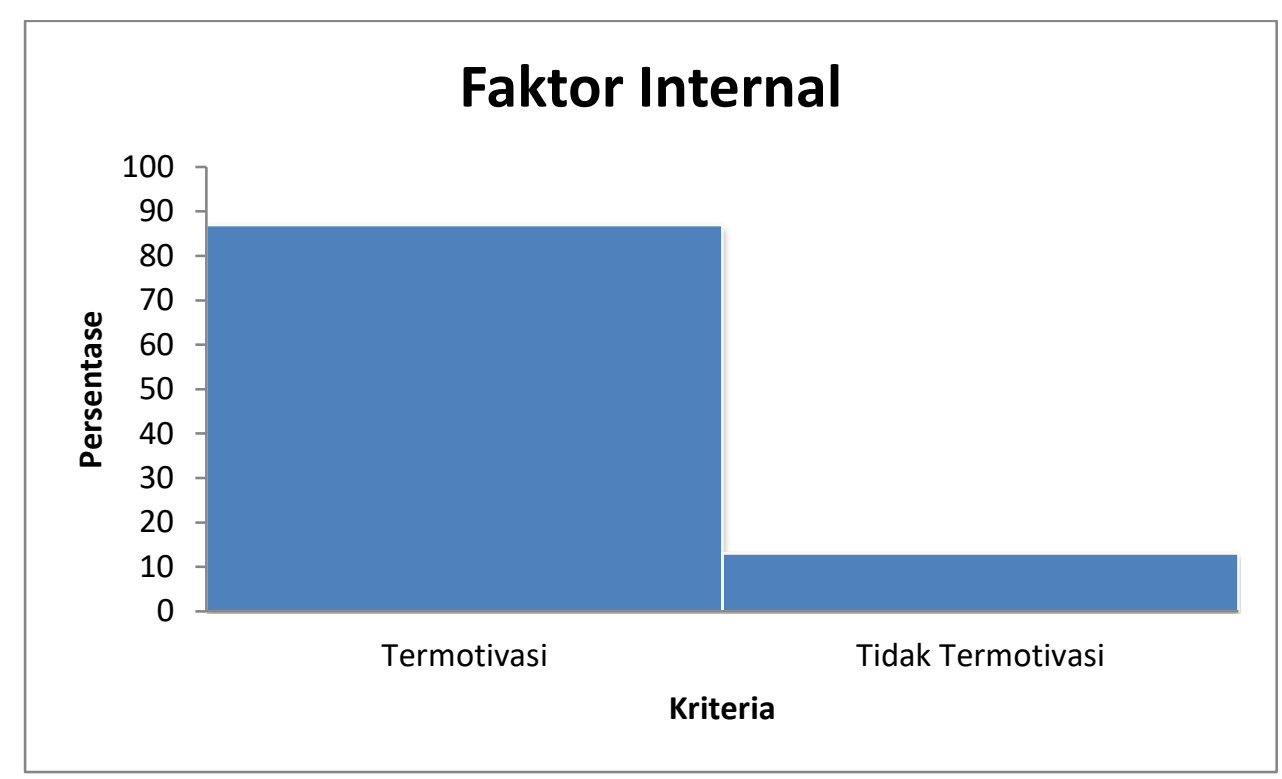

Gambar 1. Persentase Dokumentasi Peneliti

Berdasarkan tabel 2 dan diagram di atas, maka disimpulkan bahwa siswa yang termotivasi mengikuti latihan renang karena faktor internal adalah sebanyak $79,80 \%$ dengan kriteria tinggi atau 21 orang dan yang menyatakan tidak termotivasi karena faktor internal adalah sebanyak 5 orang atau sebesar 20,19\% dengan kriteria rendah. Dikarenakan siswa masih sangat kurang dukungan dari pihak keluarga dalam memberi motivasi beserta apresiasi terhadap keberhasilan siswa dalam latihan dan terhadap hasil pertandingan yang telah diikuti. Siswa belum merasa santai pada saat latihan mengingat porsi latihan yang begitu penuh serta adanya hobi lain diluar latihan renang. Hadiah dalam perlombaan yang tidak begitu besar jika dibandingkan untuk biaya yang dikeluarkan selama proses latihan.

\section{b) Faktor Eksternal}

Variabel motivasi dari seluruh jawaban aspek eksternal. Hasil dari analisis sebaran angket untuk mengetahui besarnya motivasi siswa yang mengikuti ekstrakurikuler renang SD Negeri 216 Kota Palembang ditinjau dari aspek internal berdasarkan data yang diperoleh di lapangan dan setelah di analisis menggunakan rumus di atas, dapat dilihat pada tabel 3 di bawah ini:

Tabel 3. Persentase Faktor Eksternal Keriteria Persentase Frekuensi

\begin{tabular}{|c|c|c|}
\hline Ya & 87,62 & 23 \\
\hline Tidak & 12,38 & 3 \\
\hline \multicolumn{3}{|c|}{} \\
\hline \multicolumn{3}{|c|}{ Sumber : Dokumentasi Peneliti (2019) }
\end{tabular}


Tabel faktor eksternal di atas, akan di reduksi dalam bentuk diagram batang di bawah ini :

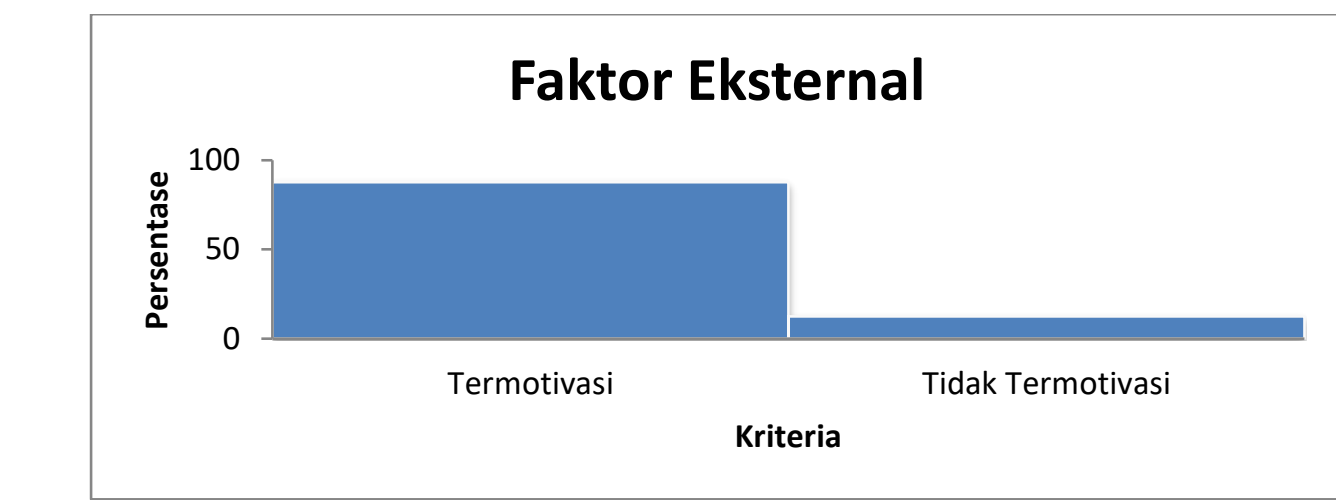

Gambar 2 Persentase Faktor Eksternal (Sumber : Dokumentasi Peneliti)

\section{PEMBAHASAN}

Berdasarkan tabel dan diagram di atas, dapat disimpulkan bahwa siswa yang termotivasi mengikuti latihan renang karena faktor eksternal adalah sebanyak $80,40 \%$ dengan kriteria tinggi atau 21 orang dan yang menyatakan tidak termotivasi karena faktor internal adalah sebanyak 5 orang atau sebesar $19,6 \%$ dengan kriteria rendah. Dikarenakan masih sedikit alumni ekstrakurikuler yang memanfaatkan kemampuannya untuk mendapat prestasi, letak sekolah beserta tempat tinggal yang jauh dari kolam renang mengakibatkan kurangnya sarana dan prasarana untuk latihan renang. Banyak guru penyeleksi saat lomba yang tidak memberi kesempatan kepada atlet pemula.

Untuk mengetahui seberapa besar persentase pemain yang termotivasi mengikuti ekstrakurikuler renang dapat dijelaskan dengan analisis di bawah ini :

$$
P=\frac{\text { Skor Perolehan Seluruh Jawaban }(F)}{\text { Skor Maksimal Seluruh Jawaban Aspek }(N)} \times 100
$$

Tabel 4

Persentase siswa mengikuti ekstrakurikuler

\begin{tabular}{|c|c|c|c|c|} 
Keriteria & SP & SM & Persentase & Frekuensi \\
\hline Ya & 1543 & 1768 & 87,27 & 23 \\
\hline Tidak & 225 & 1768 & 12,73 & 3 \\
\hline \multicolumn{5}{|c}{ Sumber : Dokumentasi Peneliti (2019) }
\end{tabular}

Tabel 4 persentase motivasi pemain di atas, akan di reduksi dalam bentuk diagram batang di bawah ini : 


\section{Tingkat Minat}

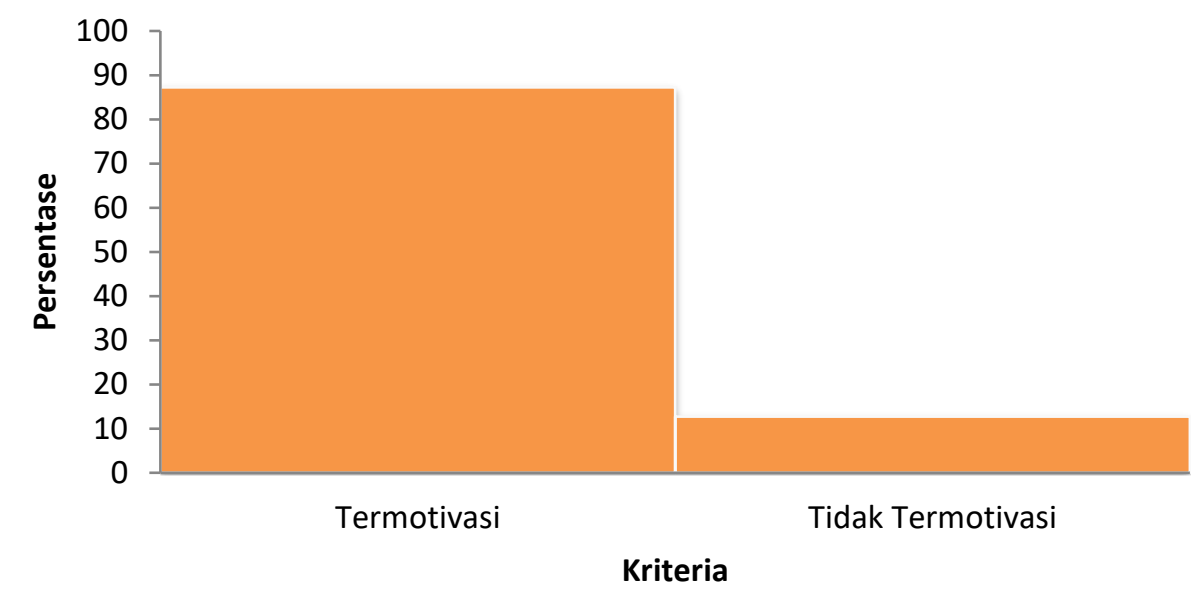

Gambar 2 Persentase Seluruh Variabel (Sumber : Dokumentasi Peneliti)

Berdasarkan tabel 4 dan diagram di atas, dapat disimpulkan bahwa siswa yang mengikuti ekstrakurikuler renang adalah $80,10 \%$ atau sebanyak 21 orang menyatakan
Ya berminat ditinjau dari kedua faktor, sedangkan sisanya $19,10 \%$ atau 5 orang siswa menyatakan belum termotivasi dari kedua faktor tersebut

\section{SIMPULAN}

Berdasarkan hasil penelitian, maka memberikan kesimpulan bahwa siswa besarnya motivasi dalam mengikuti ekstrakurikuler renang adalah $80,10 \%$ menyatakan ya yang berarti minat siswa tersebut tingi dan $19,90 \%$ menyatakan tidak yang berarti minat siswa tersebut rendahkarena bersumber dari faktor internal dan faktor eksternal. Berdasarkan hasil penelitian 19,90\% menyatakan rendahnya minat siswa ekstrakurikuler renang dikarenakan masih banyak siswa yang belum merasa enjoy karena jadwal latihan yang padat dan ekstrakurikuler renang hanya diperuntukan kelas atas, masih sedikit sekali alumni atlet berprestasi yang memanfaatkan keahliannya untuk masuk sekolah ternama, serta keadaan ekonomi siswa yang dibawah rata-rata menyebabkan banyak siswa merasa terbebani ketika harus latihan rutin mingguan dikolam renang dengan biaya sendiri. Hadiah yang didapat ketika menang kejuaraan juga lebih kecil dibanding jumlah yang digunakan semasa latihan. 


\section{DAFTAR PUSTAKA}

Arikunto.Suharsimi. 2006. Metodelogi Penelitian. Alfabeta. Bandung.

Halim, Rohman, Selamet. 2013. Jurnal. Minat Siswa Dr. Soetomo Surabaya Pada Kegiatan Ekstrakurikuler.UNESA. Imansyah, Farizal. 2017. Renang I. Noer Fikri. Palembang.

Imansyah, Farizal. 2018. Survei Faktor Yang Mempengaruhi Motivasi Mahasiswa dalam Mengikuti Mata Pembelajaran Renang. Palembang: Universitas
PGRI Palembang. Wahana Didaktika Vol. 16 No.1 Januari 2018 : 53-66.

Irawan.Andri.2009. Teknik Dasar Modern Renang.Cempaka Putih. Jakarta.

Manullang, Jujur Gunawan. 2016. Renang. Noer Fikri. Palembang.

Pralita, Era. 2015. Faktor yang Mempengaruhi Minat Siswa Dalam Ekstrakurikuler. Universitas Negeri Semarang. 